University of Nebraska - Lincoln

DigitalCommons@University of Nebraska - Lincoln

\title{
Effects of Topography and Soil Properties on Recharge at Two Sites in an Agricultural Field
}

Geoffrey N. Delin

U.S. Geological Survey

Richard W. Healy

U.S. Geological Survey

Matthew K. Landon

U.S. Geological Survey

John Karl Böhlke

U.S. Geological Survey

Follow this and additional works at: https://digitalcommons.unl.edu/usgsstaffpub

Part of the Earth Sciences Commons

Delin, Geoffrey N.; Healy, Richard W.; Landon, Matthew K.; and Böhlke, John Karl, "Effects of Topography and Soil Properties on Recharge at Two Sites in an Agricultural Field" (2000). USGS Staff -- Published Research. 224.

https://digitalcommons.unl.edu/usgsstaffpub/224

This Article is brought to you for free and open access by the US Geological Survey at DigitalCommons@University of Nebraska - Lincoln. It has been accepted for inclusion in USGS Staff -- Published Research by an authorized administrator of DigitalCommons@University of Nebraska - Lincoln. 


\title{
EFFECTS OF TOPOGRAPHY AND SOIL PROPERTIES ON RECHARGE AT TWO SITES IN AN AGRICULTURAL FIELD1
}

\author{
Geoffrey N. Delin, Richard W. Healy, Matthew K. Landon, and John Karl Böhlke ${ }^{2}$
}

\begin{abstract}
Field experiments were conducted from 1992 to 1995 to estimate ground water recharge rates at two sites located within a 2.7-hectare agricultural field. The field lies in a sand plain setting in central Minnesota and is cropped continuously in field corn. The sites are located at a topographically high (upland) site and a topographically low (lowland) site in an effort to quantify the effects of depression focusing of recharge. Three site-specific methods were used to estimate recharge rates: well hydrograph analysis, chlorofluorocarbon age dating, and an unsaturated zone water balance. All three recharge methods indicated that recharge rates at the lowland site (annual average of all methods of $29 \mathrm{~cm}$ ) exceeded those at the upland site (annual average of $18 \mathrm{~cm}$ ). On an annual basis, estimates by the individual methods ranged from 12 to 44 percent of precipitation at the upland site and from 21 to 83 percent at the lowland site. The difference in recharge rates between the sites is primarily attributed to depression focusing of surface water runon at the lowland site. However, two other factors were also important: the presence of thin lamellae at the upland site, and coarser textured soils below a depth of $1.5 \mathrm{~m}$ at the lowland site.

(KEY TERMS: focused recharge; chlorofluorocarbon age dating; hydrograph analysis; ground water.)
\end{abstract}

\section{INTRODUCTION}

This research was motivated by the need to gain an understanding of the variability of ground water recharge within an individual agricultural field and the factors that influence that variability. It is well recognized that surface and subsurface runoff to topographic lowlands can focus recharge at the subregional and local scales (Meyboom, 1966; Miller et al., 1985; Fortin et al., 1991) and at microtopographical scales (Schuh et al., 1993a, 1993b). Variations in recharge rates by more than a factor of two over distances of tens to hundreds of meters have been inferred from distributions of environmental tracers in some unconfined aquifers (e.g., Robertson and Cherry, 1989; Dunkle et al., 1993; Reilly et al., 1994; Solomon et al., 1995). Several studies have quantified vertical and horizontal variability of soil properties in the unsaturated zone (Nielsen et al., 1973; Healy and Mills, 1991; Istok et al., 1994). However, there is a dearth of studies concerning how these variabilities affect recharge rates. This study was undertaken to evaluate how the combined effects of variations in soil properties and in surface topography affect ground water recharge rates.

Spatial variability of soil properties affects the pathways and rates of water movement through the unsaturated zone (Delhomme, 1979; Sharma et al., 1980; Russo and Bresler, 1981). It is well recognized that soil properties influence the transport of agricultural chemicals to the water table (Biggar and Nielsen, 1976; Schot and van der Wal, 1992; Spalding and Exner, 1993). Many earlier studies concentrated on the effects of soil properties in the root zone because important processes affecting the transport of agricultural chemicals occur there and because of the ease of data collection compared to lower portions of the unsaturated zone. However, the variability of soil properties below the root zone also is important in controlling water movement through the unsaturated zone. Preferential flow paths can develop at depth in the unsaturated zone from soil heterogeneities (Philip et al., 1989) and from textural discontinuities (Kung,

1Paper No. 99095 of the Journal of the American Water Resources Association. Discussions are open until August 1, 2001.

2Respectively, Hydrologist, U.S. Geological Survey, 2280 Woodale Drive, Mounds View, Minnesota 55112; Research Hydrologist, U.S. Geological Survey, Denver Federal Center, MS 413, Lakewood, Colorado 80225; Hydrologist, U.S. Geological Survey, 406 Federal Bldg., 100 Centennial Mall North, Lincoln, Nebraska 68508; and Hydrologist, U.S. Geological Survey, 431 National Center, MS 431, Reston, Virginia 20192 (E-Mail/Delin: delin@usgs.gov). 
1990). Occurrence of heterogeneities, textural discontinuities, and preferential flow paths at depth in the unsaturated zone may affect the movement of water and agricultural chemicals to the water table.

This paper presents results of a study to compare estimates of ground water recharge at two sites within an agricultural field. The sites were located in an upland and a lowland area of an undulating glacial outwash sand deposit used for crop production. Dye tracer tests were conducted at both sites and detailed information was collected on soil properties in an effort to determine the reasons for any differences in estimated recharge rates. Three site specific methods were used to estimate recharge rates: well hydrograph analysis, chlorofluorocarbon age dating, and unsaturated zone water balance. These estimates were also compared to estimates based on a general water balance and stream hydrograph analysis. Results of the tracer testes were used to assess the importance of preferential flow paths on water movement through the unsaturated zone.

\section{SITE CHARACTERISTICS}

The research was done at a topographically high site (upland, R2) and a topographically low site (lowland, R1) within a 2.7-hectare field near Princeton, Minnesota, that was cropped during the growing season in field corn (Figure 1). The upland and lowland sites were about $78 \mathrm{~m}$ apart and differed in land-surface elevation by $1.4 \mathrm{~m}$ (slope of about 0.02 ). The R 1 and $\mathrm{R} 2$ sites were selected for research in part because the slope between them is relatively steep (Figure 1). During 1992 to 1995 , depth to the water table at the upland and lowland sites fluctuated between 4.0 and $4.4 \mathrm{~m}$ and 2.6 and $3.0 \mathrm{~m}$, respectively. Although the range in water table fluctuation is the same at each site, the rise in water table following a significant recharge event such as spring recharge was greater beneath the lowland site, resulting in a mound forming in the water table locally. The mounds in the water table beneath lowland areas typically develop during May and June each year but dissipate after about one month, resulting in a relatively flat water table. The deepest water levels occurred during the winter months when the ground was frozen.

Water levels were measured in wells located in eight other upland and four other lowland locations at the research site (Figure 1) to provide additional estimates of recharge based on well hydrograph analysis. Because of spatially variable recharge, the direction and velocity of ground water flow in the surficial aquifer varied seasonally between 1992 and 1995 . Throughout much of each year, ground water flow
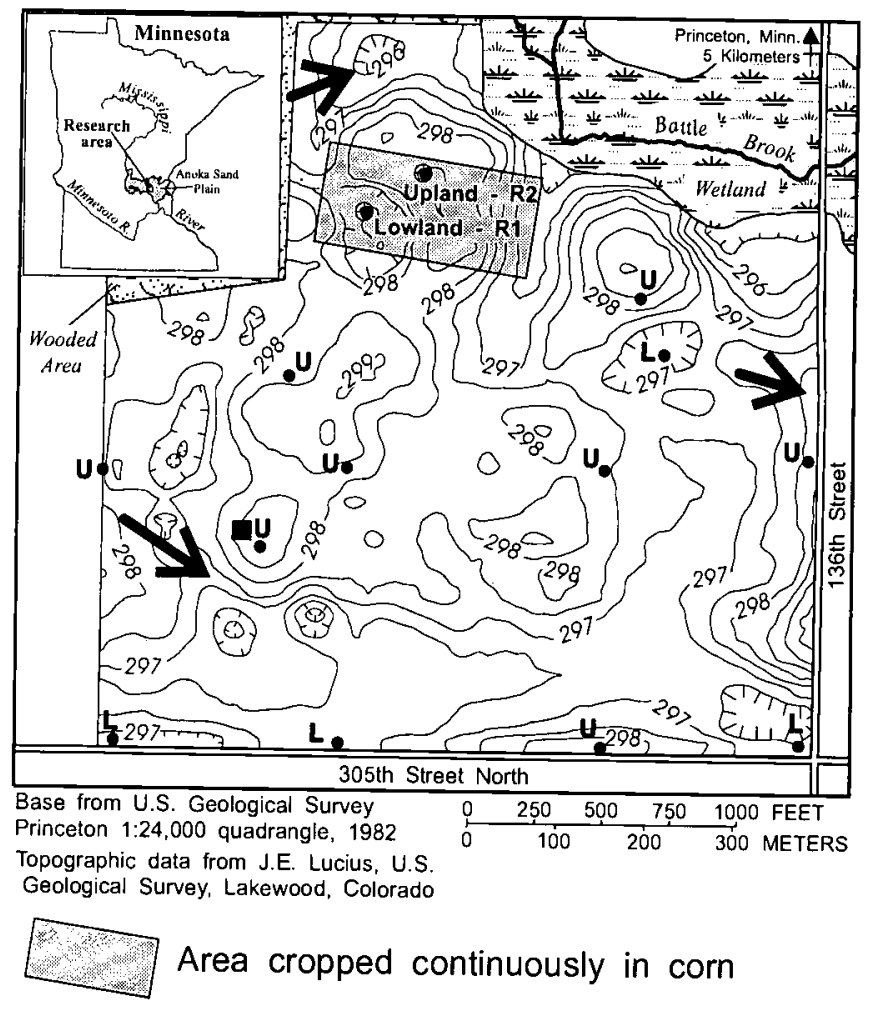

Area cropped continuously in corn

-298- Topographic contour-Contour interval 0.5 meters.

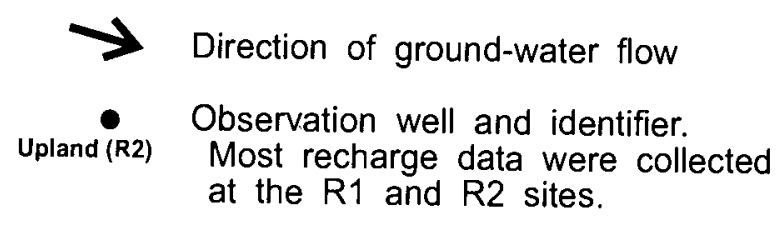

【 Additional site where recharge was estimated by hydrograph analysis: $\mathrm{U}$ - upland setting

L - lowland setting - University of Minnesota
climatological station

Figure 1. Topography and Layout of the Research Area Near Princeton, Minnesota.

was from the lowland site toward the upland site. Ground water velocities typically varied seasonally from about 7 to $15 \mathrm{~cm} / \mathrm{d}$ and horizontal hydraulic gradients varied from about 0.001 to 0.002 (Delin et al., 1994). The measured vertical hydraulic gradients at the upland and lowland sites were less than 0.002 . Natural precipitation totals were $52,77,66$, and 70 $\mathrm{cm}$ for 1992, 1993, 1994, and 1995, respectively (Figure 2), with an average of $66 \mathrm{~cm} / \mathrm{yr}$. This average is about 15 percent less per year than the $78 \mathrm{~cm}$ of mean annual precipitation from 1961 to 1992 (U.S. Dept. of Commerce 1961-1992). Mean pan evaporation for the period 1992 to 1995 was about $80 \mathrm{~cm}$ per year. Mean 
monthly temperatures (1951-1980) varied from about $21^{\circ} \mathrm{C}$ in July to about $-14^{\circ} \mathrm{C}$ in January (Baker et al., 1985). The cornfield was cultivated using full-width tillage with broadcast application of fertilizers and pesticides.

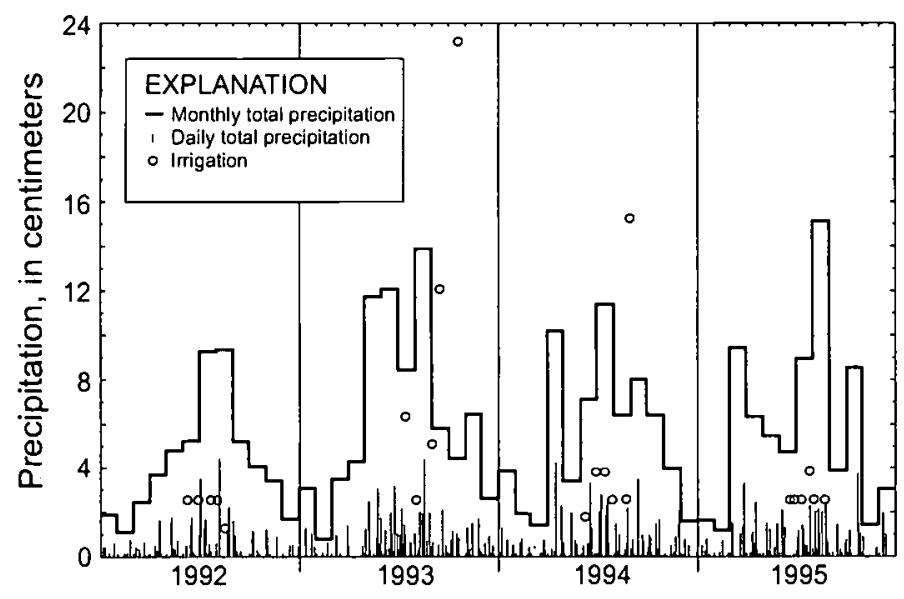

Figure 2. Daily and Monthly Precipitation at the Upland and Lowland Sites.

Soils at the upland and lowland sites are mixed, frigid Argic Udipsamments, with less than 1 percent organic matter (U.S. Dept. of Agriculture, 1968), and are underlain by glacial outwash deposits. Topsoil at the upland and lowland sites is 0.4 and $0.8 \mathrm{~m}$ thick, respectively (Delin et al., 1997). Soils in the unsaturated zone at the upland site are generally finer and better sorted than at the lowland site (Delin et al., 1996). Based on results of Keen and Shane (1990), the greater accumulation of fine-grained material at the upland site likely is due to aeolian forces that shaped the landscape and formed depressions after recession of the glacial melt waters. Grain size in the saturated zone at both sites is coarse to very coarse sand with some gravel. Delin et al. (1994) provide a detailed description of the local hydrogeology and farming practices.

\section{METHODS}

Soil moisture profiles were measured at each site with two sets of time-domain reflectometry (TDR) probes installed at depths of $0.2,0.4,0.6,0.8,1.0,1.5$, $2.0,2.5$, and $3.0 \mathrm{~m}$. Water levels were measured continuously in a water table well installed at each site using a shaft encoder connected to a central datalogger. These water levels were checked and calibrated at least weekly using hand measurements. Therefore, errors associated with water level measurements are considered insignificant in the recharge estimates based on hydrograph analysis. Observation wells were also installed in the middle and at the base of the surficial aquifer at both sites to evaluate vertical head gradients. Multiport wells (Delin and Landon, 1996b) were installed at both sites to facilitate collection of water samples in the upper $12 \mathrm{~m}$ of the saturated zone. Each multiport well consisted of six, $0.6-\mathrm{cm}$ o.d. stainless-steel tubes housed in a $5.1-\mathrm{cm}$ i.d. polyvinyl chloride (PVC) casing. Each tube exited the PVC casing and had a $3-\mathrm{cm}$ long screened interval (port). The sampling ports were installed at 50-200 $\mathrm{cm}$ intervals. A total of eleven ports were installed at each site.

\section{Field Techniques for Soil Properties and Dye Movement}

A dye tracer experiment was conducted to help visualize flow paths at the $\mathrm{cm}$ to $\mathrm{m}$ scale and to assess the importance of soil heterogeneity in controlling water movement through the unsaturated zone. A detailed description of the methods used in the test is given by Delin et al. (1996) and a brief overview is provided here. A 3 percent solution by volume of rhodamine WT dye in water was applied uniformly to a $3.5-\mathrm{m}$ by $6-\mathrm{m}$ area at each site. Rhodamine WT dye was selected for this study because it has been used successfully in other studies (Omoti and Wild, 1979; Trudgill, 1987; Kung, 1990). Approximately $12 \mathrm{~L}$ of dye solution were applied eight times at 10-day intervals (96-L total) from July 5 through September 13 , 1991. The total amount of dye solution applied ( 0.5 $\mathrm{cm}$ ) was much less than the total rainfall from July 5 through October 22, $1991(30 \mathrm{~cm})$. Beginning on October 22,1991 , a trench approximately $3-\mathrm{m}$ long and 2 $m$ wide was excavated in the middle of each dye application area. The depth of each trench was increased by intervals of $0.5 \mathrm{~m}$ to a total depth of 2.0 $\mathrm{m}$. The long walls of each trench were aligned with the corn rows.

Soil samples $\left(20 \mathrm{~cm}^{3}\right.$ each) were collected from the walls and bottom of each trench for measurements of grain-size distribution, bulk density, total organic-carbon content, volumetric moisture content $\left(\theta_{v}\right)$, and dye fluorescence. About 20 samples were collected at regularly spaced intervals of about $1.0 \mathrm{~m}$ horizontally and $0.5 \mathrm{~m}$ vertically from both the northern $(N)$ and eastern $(E)$ walls of each trench. About 60 and 25 samples were collected at irregular spacing from the southern $(S)$ and western $(W)$ walls, respectively, to facilitate geostatistical analysis. About 20 samples 
were also collected at regularly spaced intervals from both the $S$ and $W$ walls and from the trench floors at each 0.5-m depth interval.

A total of 32 undisturbed soil cores were collected from the $S$ and $W$ trench walls for measurements of saturated hydraulic conductivity. Eighty undisturbed cores were also collected for determination of moisture retention characteristics. These samples were obtained by pushing a $5-\mathrm{cm}$ i.d. by $8-\mathrm{cm}$-long thin wall brass tube horizontally into the trench wall. Each of these samples was also used for determination of grain size distribution and bulk density.

\section{Laboratory Techniques for Soil Properties and Dye Movement}

Moisture retention curves were determined by desorbing the undisturbed cores in Tempe cells, according to the method of Richards (1965). Eight different soil suctions were applied to the cells: $25,50,75,100$, $125,150,175$, and $400 \mathrm{~cm}$ of water. A least squares routine was used to determine the parameters in the following van Genuchten $(1978,1980)$ equation for each core based on the moisture retention data:

$$
S_{e}=\left[1 /\left(1+(\alpha h)^{n}\right)\right]^{m}
$$

where $S_{e}$ is effective saturation or $\left(\theta_{v}-\theta_{r}\right) /\left(\phi-\theta_{r}\right) ; \theta_{v}$ is volumetric moisture content; $\theta_{r}$ is residual moisture content; $\phi$ is porosity; $\alpha$ is a scaling factor $\left(\mathrm{cm}^{-1}\right) ; h$ is the absolute magnitude of pressure head; and $n$ and $m$ are dimensionless curve fitting parameters with $m=1-1 / n$.

Saturated hydraulic conductivities (Ks) were measured in a triaxial system by a constant flow method (Olsen et al., 1988, 1991). Effective stresses to the system were varied between 0.35 and $2.81 \mathrm{~kg} / \mathrm{cm}^{2}$. Soil analyses were conducted according to methods in Klute (1986). Porosity was calculated from bulk density assuming a grain density of $2.65 \mathrm{gm} / \mathrm{cm}^{3}$. Rhodamine WT dye was eluted from the soil samples by thoroughly mixing each $20-\mathrm{cm}^{3}$ soil sample with 200 $\mathrm{ml}$ of deionized water. The eluted dye and water mixture was then inserted into a Turner Designs Model 10 fluorometer for determination of relative dye concentration. Use of brand names in this report is for identification purposes only and does not constitute endorsement by the U.S. Geological Survey.

\section{Estimation of Ground Water Recharge}

Because of the inherent errors in any technique for estimating recharge rates, three site specific methods were applied in this study: well hydrograph analysis, an anthropogenic environmental tracer, and an unsaturated zone water balance. These site specific methods were compared to estimates based on a general site water balance and stream hydrograph analysis. For the purpose of this investigation, ground water recharge is defined as the amount of water from local precipitation that reaches the water table. A recharge event is defined as the movement of a pulse of water through the unsaturated zone following snowmelt or rainfall that results in a measurable rise in the water table. Several recharge experiments were conducted to evaluate the effects of ground water recharge related to topography. The experiments began by applying approximately $2-15 \mathrm{~cm}$ of water with a linear move irrigation system. Recharge rates were estimated based on soil moisture and water level measurements made during each experiment.

Unsaturated Zone Water Balance. The unsaturated zone water-balance (UZWB) method is based on the premise that water in the soil above the corn plant rooting depth moves upward in response to evapotranspiration (ET) and that water below that depth drains downward to the water table as recharge. Corn plants withdraw soil water for growth during the growing season, which is most intensive during June through August each year. Consequently, water flux through the unsaturated zone is reduced during the growing season. Evaporation also reduced water flux during the growing season, as well as during other times of the year (Reicosky et al., 1995). Seasonal variation in corn root distribution was investigated rigorously within the upper $2 \mathrm{~m}$ at the research site (Laboski, 1995; Laboski et al., 1998). Results indicated that the corn roots had similar rooting depths during each year of the study. Based primarily on results of that study, the depth of the ET/drainage boundary was varied seasonally for this study (Table 1). The ET/drainage boundary was deepest from mid-June through September due to the relatively high rate of ET during that period. The UZWB method is analogous to the zero-flux plane method (Richards, 1956) in which the depth of the ET/ drainage boundary (or zero flux plane) is measured using soil water tensiometers. Ten tensiometers were installed at both the upland and lowland sites for this purpose, however the instruments failed and the measured data could not be reliably used.

To estimate recharge for the UZWB method, changes in soil moisture content were integrated over time for the region between the ET/drainage boundary and the water table (Figure 3): 


$$
R\left(t_{j}\right)=\sum_{i=0}^{M}\left[\theta v_{i}\left(t_{j}\right)-\theta v_{i}\left(t_{j-1}\right)\right] \Delta z_{i}
$$

where $i$ is an index to the TDR probes equal to zero for the probe nearest the water table increasing upward to a value of $M$ for the TDR probe nearest the ET/drainage boundary; $\theta v_{i}\left(t_{j}\right)$ is the soil moisture content at sample point $i$ and time $t_{j}$; and $\Delta z_{i}$ is vertical distance of the unsaturated zone represented by measurements at each TDR probe $i(\mathrm{~cm})$. The time interval over which recharge was estimated equaled the difference in time between the time of maximum soilmoisture storage during the recharge event and the time of minimum soil-moisture storage immediately following the recharge event. The annual rate of recharge is the sum of the individual recharge events during a given year.

TABLE 1. Location of the ET/Drainage Boundary Beneath the Upland and Lowland Sites.

\begin{tabular}{lc}
\hline \multicolumn{1}{c}{ Effective Dates } & $\begin{array}{c}\text { ET/Drainage Boundary } \\
\text { Depth Below Land } \\
\text { Surface* (cm) }\end{array}$ \\
\hline January 1 through March 30 & 0 \\
April 1 through May 15 & 5 \\
May 16 through June 15 & 15 \\
June 16-30 & 30 \\
July 1-15 & 60 \\
July 16-31 & 75 \\
August 1-15 & 60 \\
August 16-31 & 40 \\
September 1-30 & 30 \\
October 1-31 & 5 \\
November 1 through December 31 & 0 \\
\hline
\end{tabular}

*Based on corn root depths and evaporation estimates.

Recharge by the UZWB method was calculated for each precipitation event that exceeded about $1.5 \mathrm{~cm}$ and produced a wetting front below the ET/drainage boundary. For events during which there was instrument failure, regression models were used to estimate recharge rates. Accuracy of the UZWB method is limited by: (1) failure to detect constant recharge that occurs in the absence of measurable changes in $\theta v,(2)$ failure to account for recharge that occurs through preferential flow pathways that are not monitored with the TDR probes, (3) inaccuracies in measurements of $\theta v$, and (4) differences between the corn root depth and the zero-flux plane.

\section{Upland site}

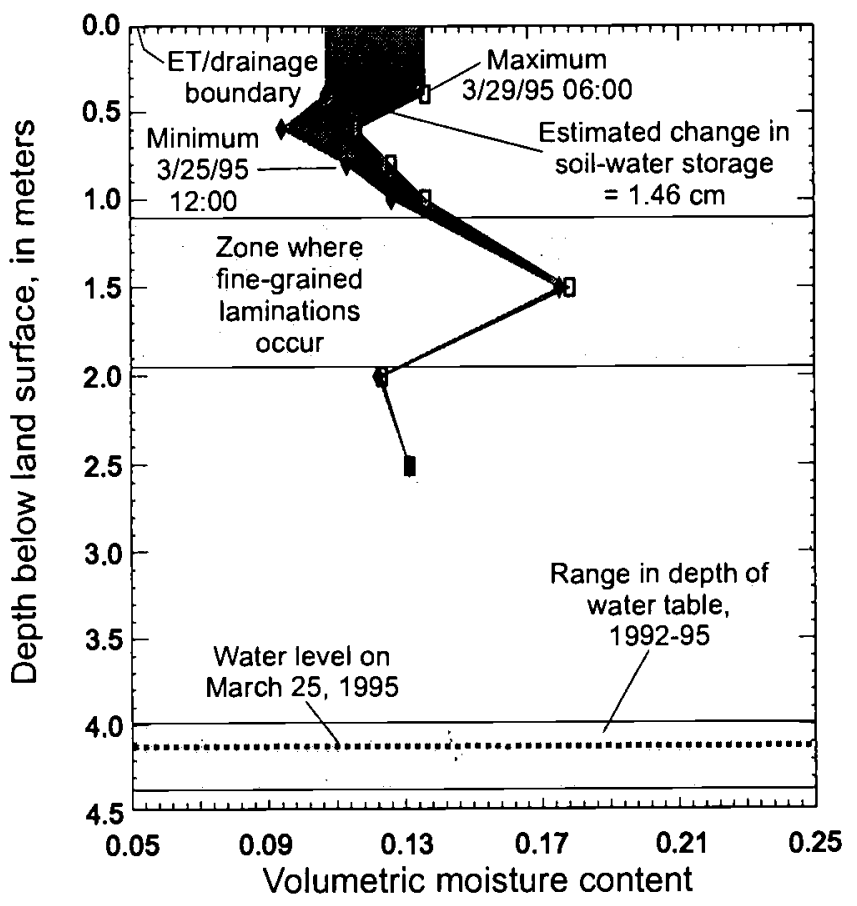

Lowland site

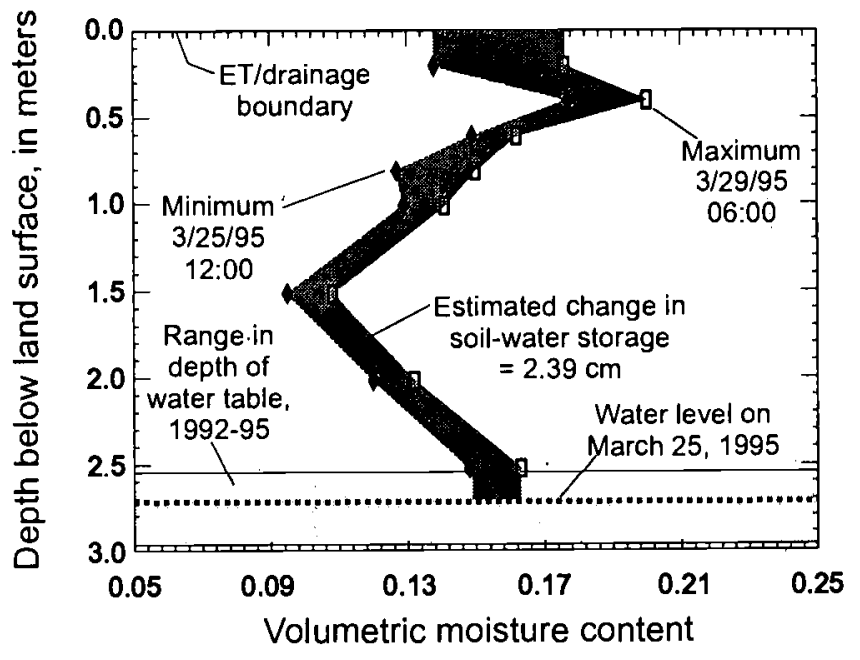

Figure 3. Vertical Profiles of Volumetric Moisture Content at the Upland and Lowland Sites for the March 25, 1995, Recharge Event. Retention of water above fine grained laminations is the most likely cause of the increased soil moisture near the $1.5-\mathrm{m}$ depth at the upland site.

Hydrograph Analysis. The method of well hydrograph analysis is based on relating changes in water table elevation measured in a well with changes in the amount of water stored in the aquifer (Rasmussen 
and Andreason, 1959). The change in storage is attributed to ground water recharge. Recharge, $R\left(t_{j}\right)$, estimated by this method can be expressed for each recharge event as:

$$
R\left(t_{j}\right)=S_{y}{ }^{*} \Delta H\left(t_{j}\right)
$$

where $R\left(t_{j}\right)$ is recharge occurring between times $t_{j}$ and $t_{j-1}(\mathrm{~cm}) ; S_{y}$ is specific yield of the aquifer (dimensionless); and $\Delta H\left(t_{j}\right)$ is the maximum water table rise attributed to the recharge event. $\Delta H\left(t_{j}\right)$ was estimated by visually extrapolating the hydrograph recession preceding the water-level rise to the date on which the water-level peak occurred. Therefore, $\Delta H\left(t_{j}\right)$ equals the difference between the projected waterlevel decline and the peak of the hydrograph on the day of the peak water level rise. These numbers were obtained using a specific yield of 0.27 that was determined by subtracting field capacity of 0.14 (from the upper $30 \mathrm{~cm}$ of the unsaturated zone) from average total porosity of 0.41 . This value was within the range expected based on grain size distribution (Johnson, 1967) for the coarse to very coarse sand in the capillary and saturated zones. The method was applied to each of the recharge events for which the UZWB method was applied. The water levels typically increased greater than about one $\mathrm{cm}$ for each of the events to which this method was applied.

The method of hydrograph analysis is simple to apply but is limited by failure to detect slow, or constant, recharge that occurs in the absence of relatively rapid changes in the water table, and by the following assumptions: (1) that recharge is the only process causing the water table to rise, (2) that recharge is represented in the measured water level rises, and (3) that specific yield is constant. Detailed error analysis of this method is well documented (Duke, 1972; Gillham, 1984; Sophocleous, 1991).

Chlorofluorocarbon Age Dating. The method of environmental tracers was based on chlorofluorocarbon $\mathrm{CCl}_{2} \mathrm{~F}_{2}$ (CFC-12) age dating techniques for ground water (Plummer and Busenberg, 1999). Recharge dates of ground water at various depths below the water table at the upland and lowland sites were estimated from measured concentrations of CFC-12 in ground water collected in July 1993 and August 1994. It was assumed that the waters equilibrated with air in the unsaturated zone before being isolated from air in the saturated zone, thereafter retaining CFC-12 concentrations proportional to the atmospheric concentrations during infiltration.

The year of recharge for each sample was determined by matching the measured CFC- 12 concentration in the sample, converted to an equivalent partial pressure based on solubility data at the temperature of recharge (Warner and Weiss, 1985), with the appropriate year in the historical record of CFC-12 partial pressures in the atmosphere at Niwot Ridge, Colorado (Elkins et al., 1993; Plummer and Busenberg, 1999). CFC-12 recharge dates were calculated by assuming recharge temperatures of $7-9^{\circ} \mathrm{C}$. Concentrations of $\mathrm{Ar}$ and $\mathrm{N}_{2}$ indicate equilibration temperatures of $9 \pm 2^{\circ} \mathrm{C}$ (Böhlke et al., 1999). At $9^{\circ} \mathrm{C}$, some of the ground water collected near the water table at the research site was supersaturated slightly with CFC-12 (by as much as 12 percent) with respect to uncontaminated air at the time of collection. Temperatures as low as $6-7^{\circ} \mathrm{C}$ would be required for all samples to have been under saturated if there were no local or regional contamination. Overall uncertainties in estimated recharge dates between about 1950 and 1994 caused by uncertainties in recharge temperatures, and by analytical uncertainties, are estimated to be in the order of $\pm 2-3$ years. Recharge dates before 1950 may have somewhat larger uncertainties as concentrations approach the detection limit. Ground water ages are equal to the difference between the date of collection and the date of apparent CFC-12 equilibrium. Negative ages indicate samples that appear to have been slightly supersaturated at the assumed recharge temperature.

Ground water age depth profiles were used to estimate downward vertical ground water velocities at the water table $\left(V_{v}{ }^{\circ}\right)$ by assuming an exponential age distribution in the surficial aquifer (Vogel, 1967; Zuber, 1986):

$$
V_{\nu}{ }^{0}=(Z / \operatorname{age}(i))^{*} \ln \{Z /[Z-z(i)]\}
$$

where age $(i)$ is the age of a ground water parcel (yr); $Z$ is thickness of the saturated zone in the surficial aquifer $(\mathrm{m})$; and $z(i)$ is the depth of the parcel below the water table $(\mathrm{m})$. The average saturated-zone porosity $(\phi=0.41)$ was used to convert the vertical velocities at the water table $\left(V_{v}{ }^{o}\right)$ to ground water recharge rates $\left(R=\phi V_{v}{ }^{\circ}\right)$. The aquifer thickness $(Z)$ at each site was assumed to be equal to the difference in elevation between the water table and the top of the shallowest silt-rich unit recorded in the drilling logs (Delin et al., 1997). Recharge rates obtained with this method represent values that are averaged over the apparent age range of the samples (years to decades). Recharge cannot be estimated for single recharge events or for individual years. The method is limited in its spatial resolution because deeper waters, needed to establish an age gradient at a site, may represent water recharged at increasingly greater distances upgradient from the site. 
Other Methods. For comparison with the site specific recharge estimates, two other independent estimates of average recharge in and near the study area were obtained using a general water budget and stream hydrograph analysis. A rough approximation of the water budget over both sites was computed based on the annual water budget. Neglecting runon and runoff, precipitation should equal the sum of recharge, evapotranspiration (ET), and change in soilwater storage $(\Delta S)$. The water budget represents the period from January 1993 through December 1994, for which these data were available.

For the stream hydrograph analysis method, mean recharge in the $1,593 \mathrm{~km}^{2}$ watershed that includes the research site was estimated by using a computerized graphical technique for base flow separation (Wahl and Wahl, 1995). The method was applied to stream gaging records at U.S. Geological Survey (USGS) station 0505275000 on the Elk River near Big Lake.

\section{Statistical Techniques}

Regression statistics, univariate statistics, correlation coefficients, and significance levels were determined with the SAS software package (SAS Institute Inc., 1990). The evaluation for normality was based on the Kolmogorov-Smirnov test using a 0.01 significance level and the Student-Fisher $t$ test.

Stepwise multiple linear regression models of selected variables that control recharge were developed for the upland and lowland sites for recharge events other than spring snowmelt. Models were developed primarily to estimate recharge rates for periods of missing data. Separate models were developed for each site for recharge based on the hydrograph analysis and unsaturated zone water balance methods. The following independent variables were used in the models: (1) amount of rainfall, (2) average rainfall intensity $(\mathrm{cm} / \mathrm{hr}$ ), and (3) antecedent moisture content for the entire unsaturated zone. These were the only variables that could be quantified for each recharge event. A total of 25 and 39 data sets were used for developing the models at the upland and lowland sites, respectively. The chlorofluorocarbon recharge estimate could not be included in the regression modeling because it represents a multi-year time period, while the other data represent individual recharge events.

\section{RESULTS}

\section{Properties of Unsaturated Zone Soils}

Recharge and water movement at the upland site was affected by fine grained laminations (lamellae) that were detected in soil cores and observed in the trench walls, primarily between the $1-\mathrm{m}$ and $2-\mathrm{m}$ depth intervals (Figure 4). The lamellae are generally horizontal and continuous in lateral extent. Lamellae were not observed at the lowland site in the trench walls or in cores. Results of other investigations at the site (Tomer and Anderson, 1995; Tomer et al., 1995) indicate that such lamellae commonly extend for several meters horizontally to the side slope areas. The lamellae are $2-\mathrm{cm}$ to $20-\mathrm{cm}$ thick, cemented with iron, and contain an average of about 5 to 10 percent silt and clay compared to less than about 5 percent in adjacent horizons. The origin of the lamellae is uncertain but it has been suggested that they formed following deposition of aeolian deposits commonly found in this area. The lamellae likely contribute to lateral water movement on the decameter scale (Tomer et al., 1995).

Soils in the upper two meters at the upland and lowland sites (Table 2) are similar, being composed of about 95 percent sand and 5 percent silt and clay (Delin et al., 1996). Wu et al. (1996) examined a subset of the variables in Table 2 in other locations at the research site and found similar results. The following differences in soil properties are considered significant, however, since they are related directly or indirectly to focused recharge at the lowland site: (1) soils at the lowland site, particularly below about the 1.5-m depth, are coarser (Figure 4), (2) organic carbon content is greater at the lowland site, (3) soils at the upland site are generally more uniform, (4) standard deviations for all variables are greater at the lowland site, and (5) lamellae at the upland site.

With the exception of the lamellae, the unsaturated zone to a depth of $1.5 \mathrm{~m}$ at both sites consists mostly of well sorted fine to medium grained sand. Values of median grain size $\left(d_{50}\right)$ at the lowland site are greater than at the upland site principally because material below approximately $1.5 \mathrm{~m}$ consists of coarse to very coarse sand with fine gravel. Values of $d_{50}$ at the lowland site, for example, changed from $0.23 \mathrm{~mm}$ in the upper one meter depth to $0.40 \mathrm{~mm}$ between the one and two meter depths. In contrast, soil throughout the upper $2.4 \mathrm{~m}$ of the unsaturated zone at the upland site is fine to medium sand and $d_{50}$ did not change substantially with depth (Figure 4). The silt and clay and $O C$ contents are greater at the lowland site than at the upland site, principally in the upper $30 \mathrm{~cm}$ of 
the unsaturated zone. These features are believed to have originated from silt and organic matter that eroded from the surrounding areas and washed into the topographically lower area.

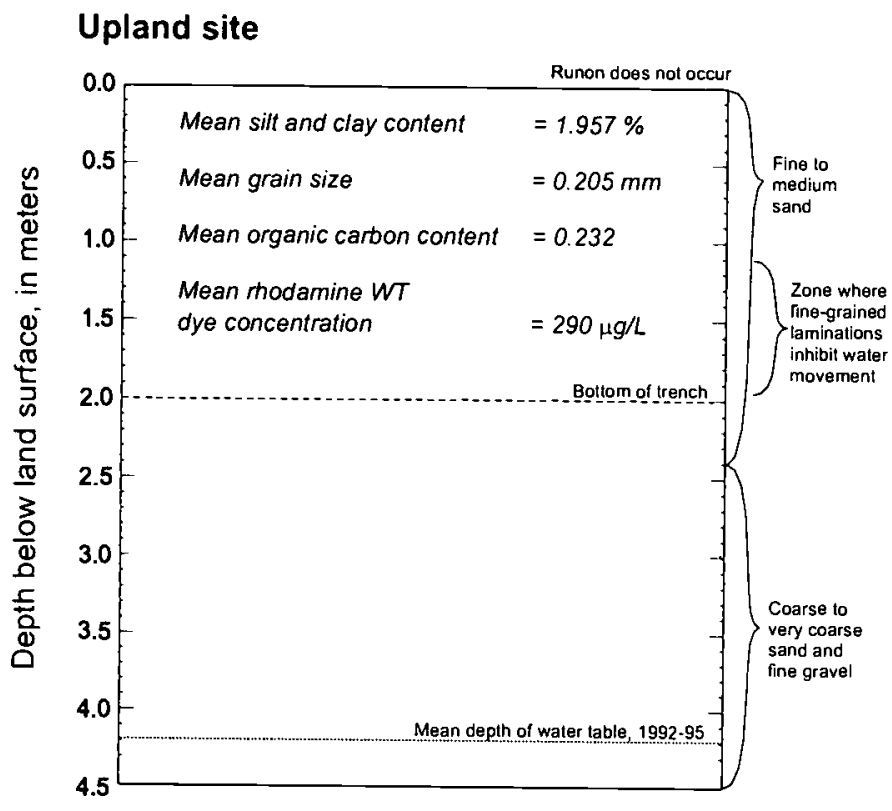

\section{Lowland site}

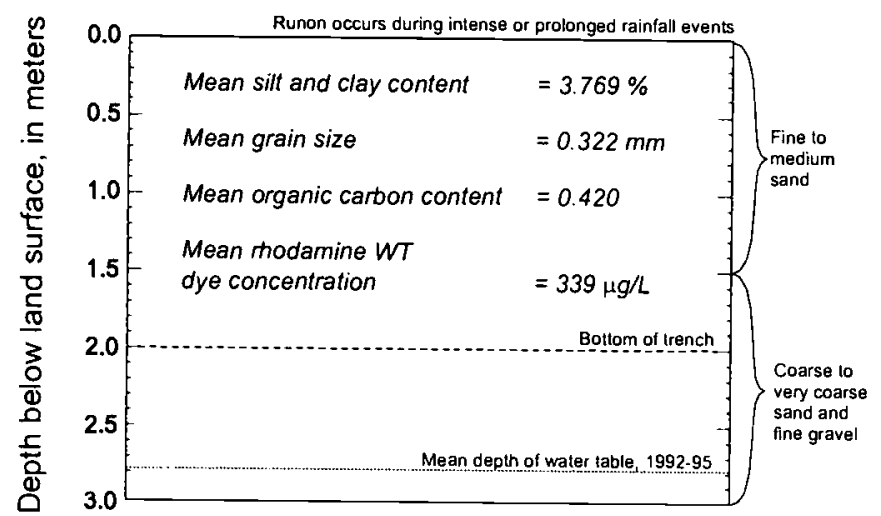

Figure 4. Soil Properties and Other Variables That contribute to Differences in Recharge at the Upland and Lowland Sites.

The greater percentage of coarse material at the lowland site contributes to a greater release of water at low suction values in the average soil moisture retention curve (Figure 5). At suctions greater than $100 \mathrm{~cm}$, however, the curves are similar for both sites.
Upland site

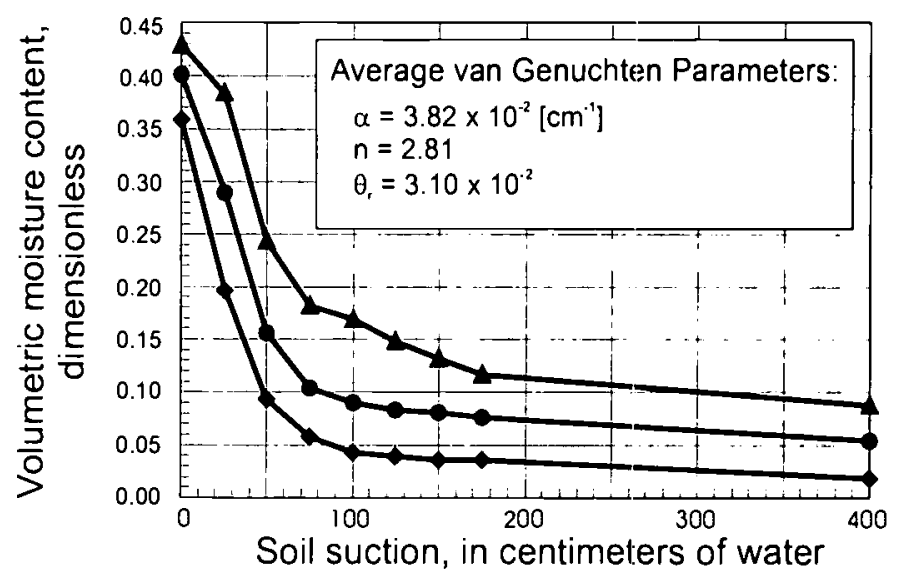

EXPLANATION
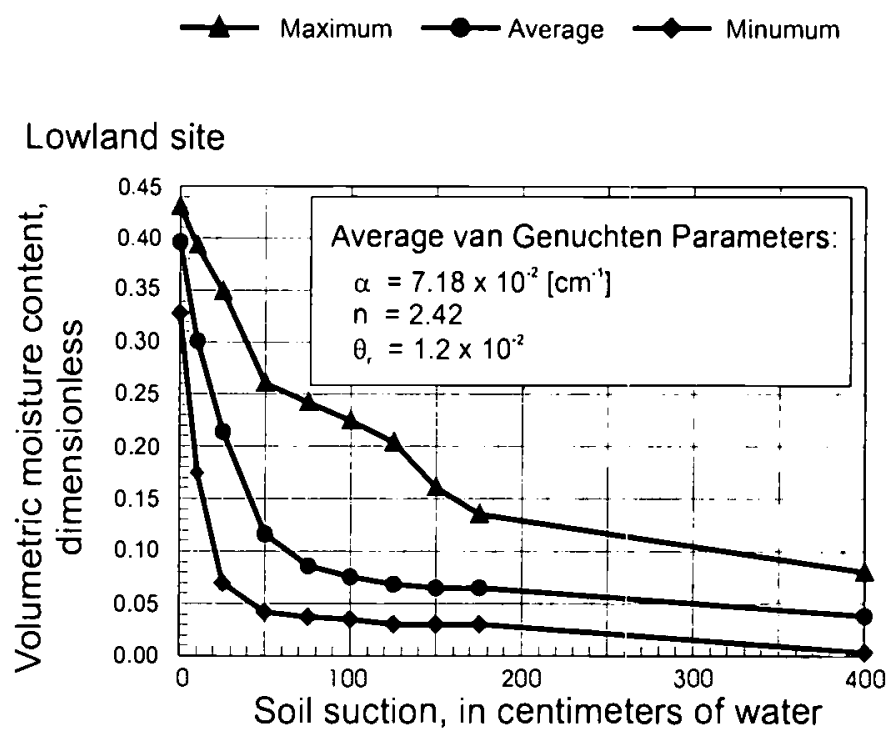

Figure 5. Moisture-Retention Characteristics at the Upland and Lowland Sites.

\section{Dye Tracer Test}

Although visible dye was most concentrated in the upper $40 \mathrm{~cm}$ at both the upland and lowland sites, large amounts of visible dye typically penetrated about twice as deep at the upland site (Delin et al., 1996). At the lowland site, much of the dye was assumed to be sorbed onto organic matter, which was more abundant near land surface than at the upland site (Table 2).

Dye generally moved through irregularly (Figure 6 ), rather than as a uniform front. Dye movement was greater beneath the furrows and less beneath the corn 
TABLE 2a. Summary of Univariate Statistics for Soil Samples From the Upper Two Meters at the Upland Site.

\begin{tabular}{|c|c|c|c|c|c|c|c|c|}
\hline $\begin{array}{l}\text { ID } \\
\text { No. }\end{array}$ & Variable & $\begin{array}{l}\text { Number } \\
\text { of } \\
\text { Samples }\end{array}$ & Mean & $\begin{array}{l}\text { Standard } \\
\text { Deviation }\end{array}$ & Median & Minimum & Maximum & $\begin{array}{l}\text { Normal } \\
\text { Distribution } \\
\text { Accepted? }\end{array}$ \\
\hline 1 & Silt and clay content (percent) & 158 & 1.957 & 1.758 & 1.560 & 0.090 & 11.158 & No \\
\hline 2 & $d_{50}$ grain size $(\mathrm{mm})$ & 158 & .205 & .029 & .209 & .095 & .355 & No \\
\hline 3 & $d_{10}$ grain size $(\mathrm{mm})$ & 177 & .098 & .019 & .098 & .023 & .173 & No \\
\hline 4 & $\begin{array}{l}\text { Rhodamine WT dye } \\
\text { concentration }\left(\mu \mathrm{g} \mathrm{L}^{-1}\right)\end{array}$ & 173 & 290. & 538. & 23. & .010 & 3888 & No \\
\hline 5 & $\rho_{b}$ (bulk density) $\left(\mathrm{g} \mathrm{cm}^{-3}\right)$ & 124 & 1.567 & .046 & 1.574 & 1.405 & 1.732 & Yes \\
\hline 6 & $\theta_{v}$ (volumetric moisture content) & 124 & .087 & .020 & .081 & .058 & .145 & No \\
\hline 7 & $\phi$ (porosity) & 124 & .409 & .018 & .406 & .346 & .470 & Yes \\
\hline 8 & S (saturation) & 124 & .213 & .055 & .195 & .136 & .392 & No \\
\hline 9 & OC (organic carbon content) & 24 & .232 & .246 & .120 & .040 & .900 & No \\
\hline 10 & $\begin{array}{l}\mathrm{K}_{\mathrm{s}} \text { (lab) (saturated hydraulic } \\
\text { conductivity from laboratory } \\
\text { analyses) }\left(\mathrm{cm} \mathrm{s}^{-1}\right)\end{array}$ & 16 & .005 & .002 & .005 & .001 & .007 & Yes \\
\hline 11 & $\alpha$ (scaling factor) $\left(\mathrm{cm}^{-1}\right)$ & 24 & .038 & .014 & .035 & .013 & .082 & No \\
\hline 12 & $n$ (curve fitting parameter) & 24 & 2.812 & .972 & 2.806 & 1.424 & 6.510 & No \\
\hline 13 & $\theta_{r}($ residential moisture content $)$ & 24 & .031 & .067 & .047 & -.274 & .071 & No \\
\hline
\end{tabular}

TABLE 2b. Summary of Univariate Statistics for Soil Samples From the Upper Two Meters at the Lowland Site.

\begin{tabular}{|c|c|c|c|c|c|c|c|c|}
\hline $\begin{array}{l}\text { ID } \\
\text { No. }\end{array}$ & Variable & $\begin{array}{l}\text { Number } \\
\text { of } \\
\text { Samples }\end{array}$ & Mean & $\begin{array}{l}\text { Standard } \\
\text { Deviation }\end{array}$ & Median & Minimum & Maximum & $\begin{array}{l}\text { Normal } \\
\text { Distribution } \\
\text { Accepted? }\end{array}$ \\
\hline 1 & Silt and clay content (percent) & 141 & 3.769 & 2.849 & 2.670 & 0.190 & 11.534 & No \\
\hline 2 & $d_{50}$ grain size $(\mathrm{mm})$ & 141 & .322 & .177 & .243 & .101 & .993 & No \\
\hline 3 & $d_{10}$ grain size $(\mathrm{mm})$ & 152 & .131 & .109 & .098 & .014 & .870 & No \\
\hline 4 & $\begin{array}{l}\text { Rhodamine WT dye } \\
\text { concentration }\left(\mu \mathrm{L} \mathrm{L}^{-1}\right)\end{array}$ & 122 & 339. & 765. & .322 & .011 & 5486. & No \\
\hline 5 & $\rho_{b}$ (bulk density) $\left(\mathrm{g} \mathrm{cm}^{-3}\right)$ & 98 & 1.559 & .054 & 1.568 & 1.218 & 1.743 & No \\
\hline 6 & $\theta_{v}$ (volumetric moisture content) & 98 & .150 & .059 & .142 & .062 & .421 & No \\
\hline 7 & $\phi$ (porosity) & 98 & .412 & .021 & .409 & .342 & .517 & No \\
\hline 8 & $\mathrm{~S}$ (saturation) & 98 & .364 & .135 & .337 & .155 & .815 & No \\
\hline 9 & OC (organic carbon content) & 28 & .420 & .383 & .265 & .030 & 1.290 & No \\
\hline 10 & $\begin{array}{l}\mathrm{K}_{\mathrm{s}} \text { (lab) (saturated hydraulic } \\
\text { conductivity from laboratory } \\
\text { analyses) }\left(\mathrm{cm} \mathrm{s}^{-1}\right)\end{array}$ & 11 & .008 & .006 & .005 & .002 & .022 & No \\
\hline 11 & $\alpha$ (scaling factor) $\left(\mathrm{cm}^{-1}\right)$ & 18 & .072 & .045 & .054 & .023 & .186 & No \\
\hline 12 & $n$ (curve fitting parameter) & 18 & 2.418 & .717 & 2.313 & 1.279 & 3.997 & No \\
\hline 13 & $\theta_{r}($ residential moisture content $)$ & 18 & .012 & .080 & .024 & -.244 & .150 & No \\
\hline
\end{tabular}




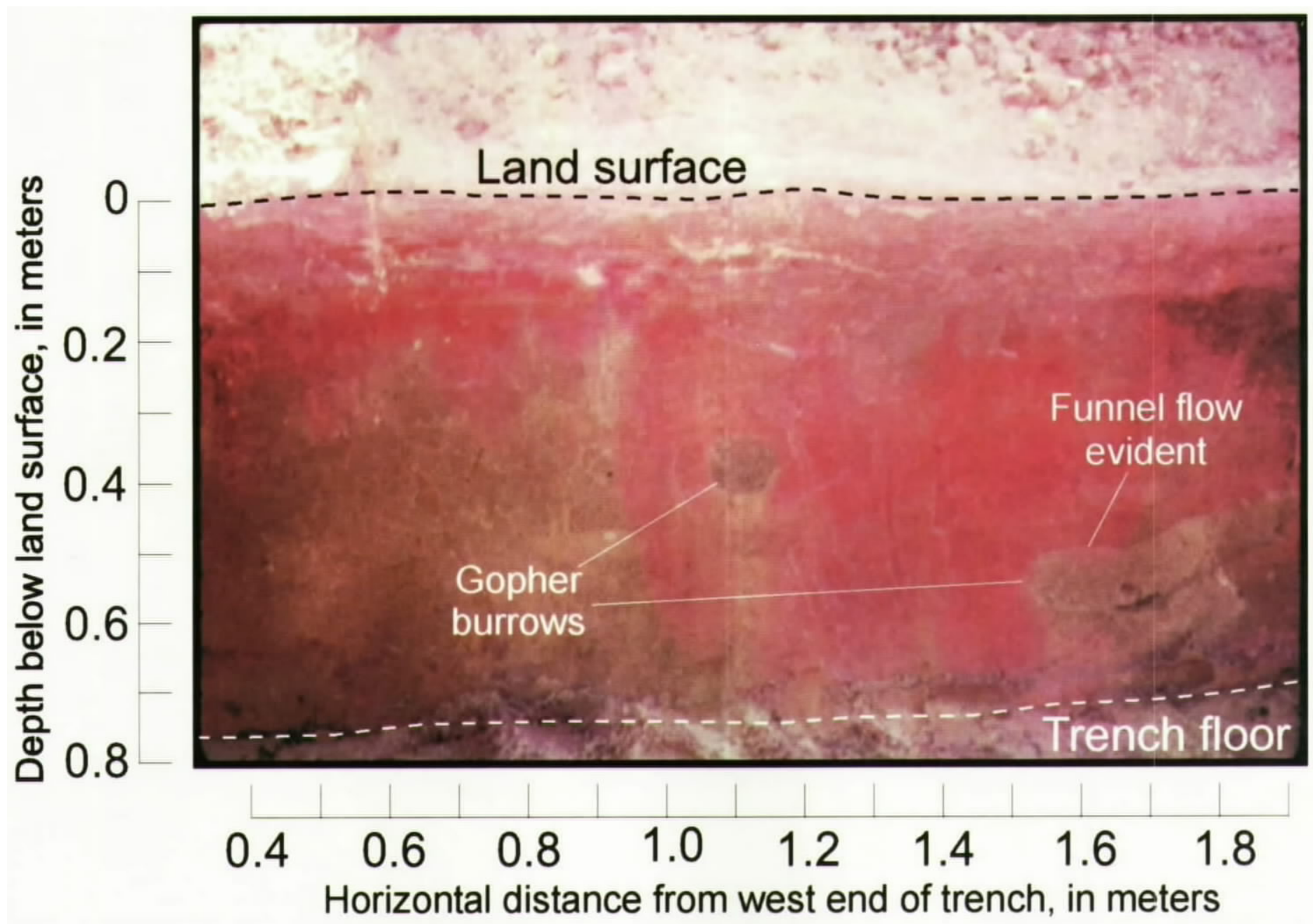

Figure 6. Dye Distribution on Trench Wall R2S, October 22, 1991. Note that the dye moved in irregular regions and moved around several gopher burrows. The gopher burrows were filled with sand that was coarser than the surrounding material.

rows. This is attributed to runoff of the applied dye solution from the side slope areas of adjacent corn rows. Within the furrows, runoff collected in microtopographic depressions that were 1 to $3 \mathrm{~cm}$ lower than the surrounding topsoil resulting in localized preferential movement of dye below land surface and focused recharge at the $\mathrm{cm}$ scale. Locations of these depressions on the surface were well correlated with elongated pulses of dye in the subsurface that resulted in highly variable dye distribution in the unsaturated zone at both sites.

Preferential movement of dye also was evident in the vicinity of plant roots. The dye stained alfalfa roots to depths as great as about $1.5 \mathrm{~m}$ (alfalfa was grown at the site from 1980-1989).

Water transporting the dye commonly avoided heterogeneities in the unsaturated zone, such as gopher burrows (Figure 6). Kung (1990) found similar results in another sand plain setting. Gopher burrows in the upper $0.5 \mathrm{~m}$ at the upland site are filled with sand grains that have average diameters about $0.03 \mathrm{~mm}$ larger than grains in the surrounding matrix. Water and dye apparently moved around gopher burrows that were less than about $8-\mathrm{cm}$ in diameter. However, funnel flow of water also moved into and through coarser sand in the burrows when water suction within pores in the overlying finer sand was less than that in the coarser sand. Based on measured dye concentrations in the multiport wells beneath both sites, recharge water carrying dye reached the saturated zone between 95 and 110 days after application began at both sites.

\section{Ground-Water Recharge Rates}

Using the well hydrograph analysis, the average recharge rate between 1992 and 1995 was $14 \mathrm{~cm} / \mathrm{yr}$ at the upland site and $18 \mathrm{~cm} / \mathrm{yr}$ at the lowland site 
(Table 3). For almost every event, the amount of recharge at the lowland site exceeded that at the upland site. There is a strong correlation $\left(R^{2}=0.92\right)$ between recharge rates at the two sites for individual recharge events using this method (Figure 7). Recharge, was not detected for recharge events of less than $1.5 \mathrm{~cm}$. Precipitation for the quantified recharge events represents 92 percent of average annual precipitation between 1992 and 1995. Focused recharge was observed beneath other lowland sites within the research area (Figure 1). Based on the hydrograph analysis method, average recharge between 1992 and 1995 beneath four other lowland sites $(14 \mathrm{~cm} / \mathrm{yr})$ was slightly greater than beneath eight other upland sites (13 cm/yr) (Table 3 ).

Ground water ages inferred from CFC-12 concentrations generally increased with depth below the water table at both sites (Figure 8). The reason for the apparent CFC-12 discrepancy (6-m depth) at the lowland site is not known. Multiport R1-10 and well R1-B were approximately $0.7 \mathrm{~m}$ apart vertically and could have sampled different flow paths. The samples from R1-10, indicating relatively low and variable apparent CFC-12 ages, also had concentrations of $\mathrm{C}_{2} \mathrm{Cl}_{3} \mathrm{~F}_{3}$ (CFC-113) that were 1.5 to 2.6 times the value expected in recharging ground water in 1993 to 1994 . The values at R1-10 were among the highest observed at the research site whereas most ground water had CFC-113 concentrations that were approximately consistent with CFC-12 ages (Böhlke et al., 1999). It is possible that the large amounts of CFC-113 contamination at R1-10 were accompanied by minor CFC-12 contamination yielding the anomalous lowland vertical apparent ages, but this cannot be proven with the available data. Hypothetical exponential age distributions (Equation 4) were computed for: (1) saturated thicknesses of $9.5 \mathrm{~m}$ at the lowland site and $11.4 \mathrm{~m}$ at the upland site (Delin et al., 1997); and (2) vertical
Hydroyraph analysis method

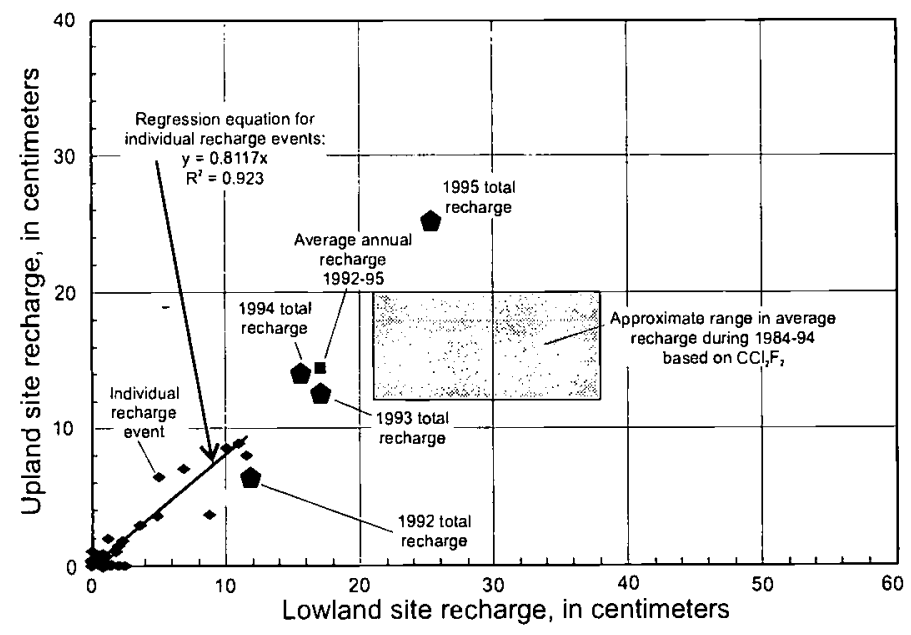

Unsaturated-zone water-balance method

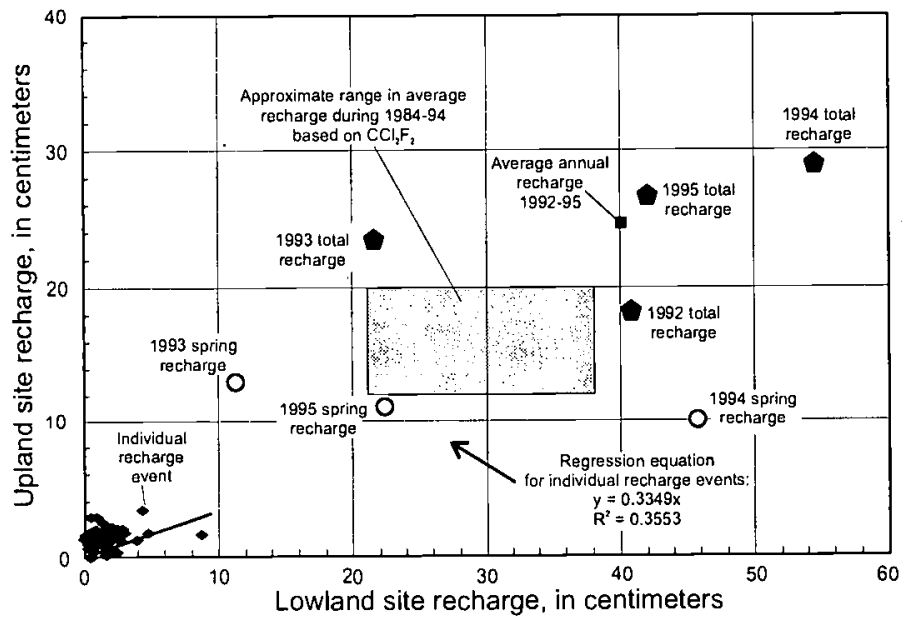

Figure 7. Recharge at the Lowland Site Versus the Upland Site Based on the Hydrograph Analysis and Unsaturated Zone Water Balance Methods, 1992-1995. The approximate range in average $\mathrm{CFC}-12$ modeled recharge rates is included for comparison (see Figure 8).

TABLE 3. Average Annual Recharge Rates at the Upland and Lowland Sites Based on Three Different Methods (in centimeters per year; recharge as a percentage of total natural precipitation is included in parentheses; $\mathrm{cm}$, centimeters; UZ, unsaturated zone; environ, environmental; -, not applicable; recharge rates for the other upland and lowland sites within the research area were made using the hydrograph analysis method).

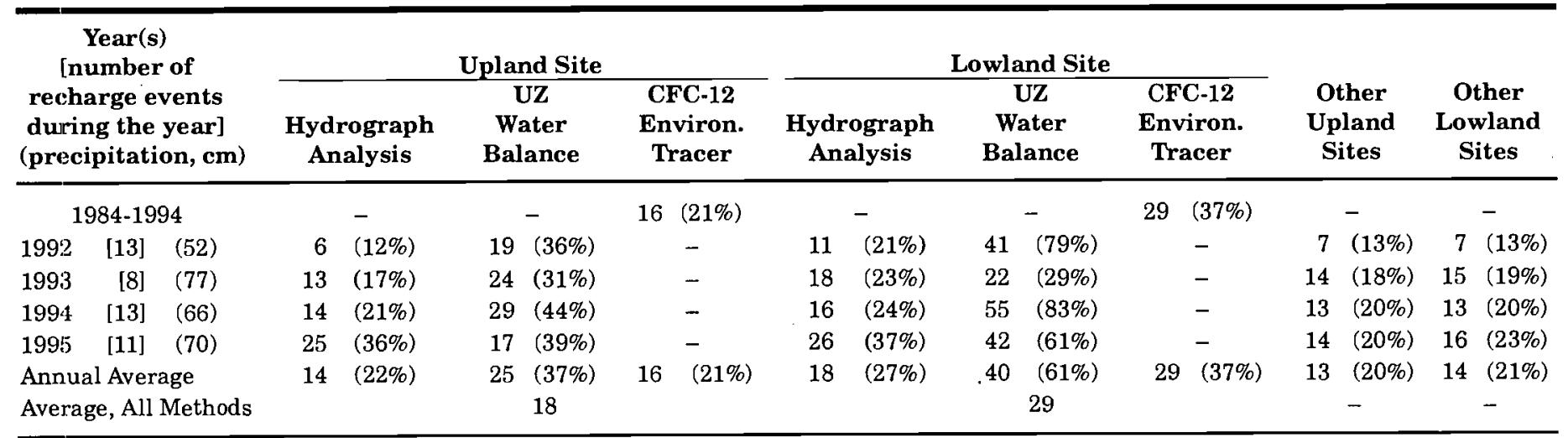


velocities of ground water near the water table of 0.7 $\pm 0.2 \mathrm{~m} / \mathrm{yr}$ at the lowland site and $0.4 \pm 0.1 \mathrm{~m} / \mathrm{yr}$ at the upland site (Figure 8 ). The apparent difference in vertical velocities between the two sites in the upper $3-4 \mathrm{~m}$ is interpreted to result from local differences in recharge rates. Because of horizontal flow, deeper ground waters beneath each site are likely to have traveled farther from their points of recharge than shallower ground waters. Thus, designation of ground waters as 'upland' or 'lowland' recharge based on the overlying topography is considered to be unreliable at depths greater than a few meters below the water table at both sites (waters more than about 5-10 years old; Figure 8). From the CFC-12 data and an average porosity of 0.41 , it is inferred that the average recharge rate in the last 10 years before sampling was about $16 \pm 4 \mathrm{~cm} / \mathrm{yr}$ near the upland site and $29 \pm 8$ $\mathrm{cm} / \mathrm{yr}$ near the lowland site (Figure 8 ). These estimates represent 21 percent and 37 percent, respectively, of mean annual precipitation between 1980 and 1993.

For the UZWB method, average recharge between 1992 and 1995 was $25 \mathrm{~cm} / \mathrm{yr}$ at the upland site and 40 $\mathrm{cm} / \mathrm{yr}$ at the lowland site (Table 3 ). Recharge was estimated for 51 percent and 26 percent of the events at the upland and lowland sites, respectively, using the stepwise multiple linear regression models (Table 4). The increased recharge at the lowland site resulted in part from the presence of coarse grained sand below the $1.5 \mathrm{~m}$ depth at the lowland site, causing relatively rapid drainage of the soils locally. Also, the presence of lamellae at the upland site caused the soil water to drain more slowly, allowing more water to be lost to ET.

For the multiple linear regression models, we expected that the rates of recharge would increase as each of the independent variables increased, which is commonly the case (Sophocleous and Perry, 1985). The regression results for both the hydrograph analysis and UZWB methods are contrary to this model, however, yielding negative coefficients for variables associated with average rainfall intensity and antecedent moisture content (Table 4). This may reflect the fact that other independent variables such as topography (runon) and soil variability, which this study has indicated are important in controlling recharge, could not be included in the regression analysis because they do not vary in time. The regression results may also reflect flaws in these methods. The y-intercept values for both methods are higher for the lowland site than for the upland site (Table 4), which is consistent with the concept of focused recharge at the lowland site. $\mathrm{R}^{2}$ values for all modes are, in general, moderately low and indicate a wide scatter of data points about the regression lines.
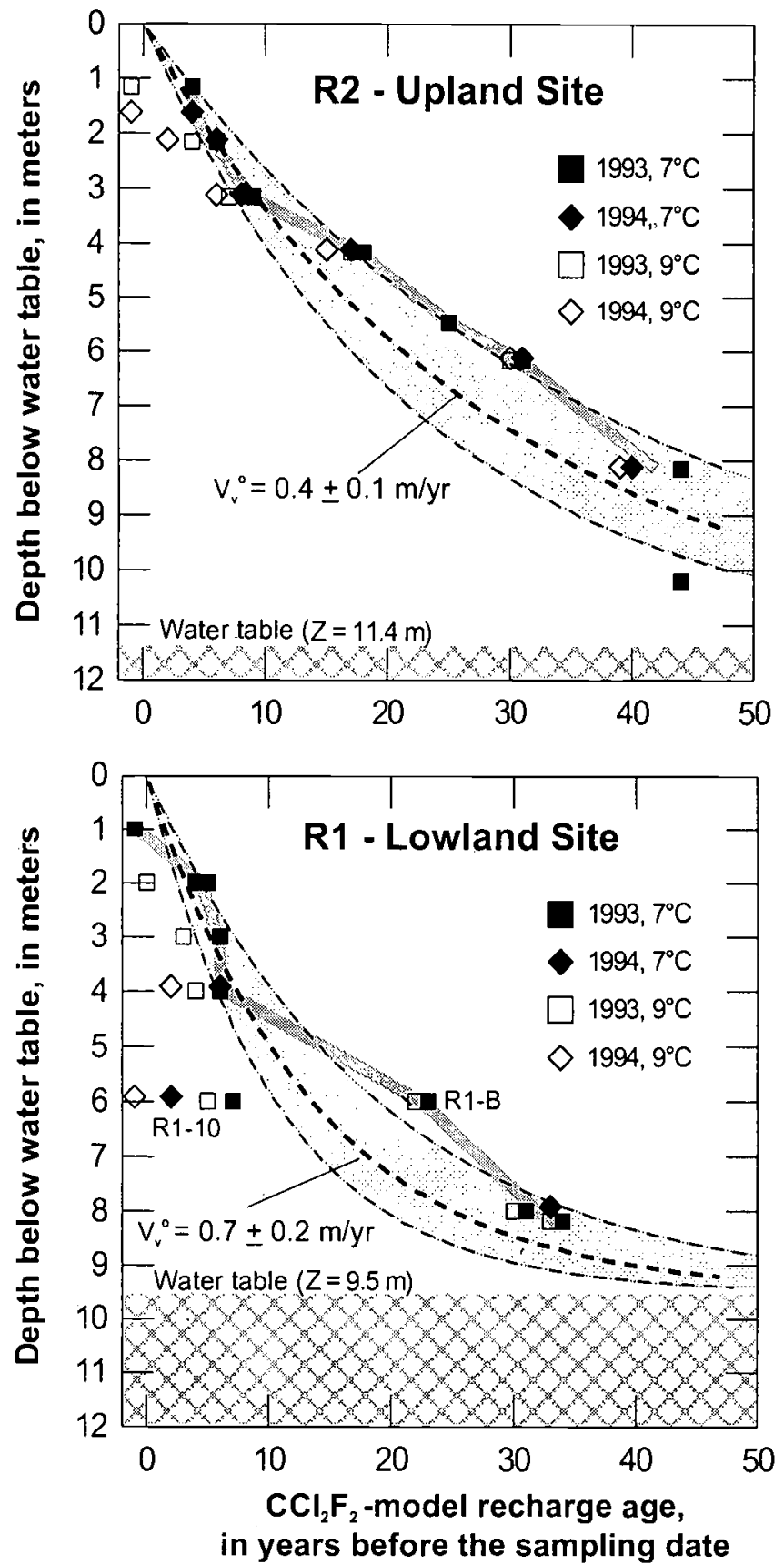

Figure 8. Variation of Ground Water Ages With Depth Below the Water Table. Ages were estimated from the concentrations of CFC-12, assuming recharge temperatures of $7^{\circ} \mathrm{C}$ and $9^{\circ} \mathrm{C}$.

Dashed curves indicate exponential age gradients (Equation 4) for varying recharge $\left(\mathrm{R}=\phi V_{v}{ }^{o}\right.$, where $V_{v}{ }^{o}$ is the vertical component of ground-water velocity at the water table and $\phi$ is porosity). The reason for the apparent age discrepancy between multiport R1-10 and well R1-B is not known, but it could indicate minor CFC-12 contamination at R1-10 (see text).

Based on individual recharge events, there is a moderate correlation $\left(\mathrm{R}^{2}=0.57\right)$ between the UZWB estimates for the two sites and a strong correlation 
TABLE 4. Formulas and $\mathrm{R}^{2}$ Values for the Multiple Linear Regression Models

(rech. hydg. anal., recharge based on the hydrograph analysis method; UZ water balance, recharge based on the unsaturated zone water balance method; precip, amount of water applied; intens, average rainfall or irrigation water application intensity; antec, antecedent moisture content for the entire unsaturated zone).

\begin{tabular}{|c|c|c|c|}
\hline Site & Dependent Variable & Independent Variables & $\mathbf{R}^{2}$ \\
\hline Upland & rech. hydg. anal. & $=(0.697) *($ precip $)+(-0.499)^{*}($ intens $)+(-0.051)^{*}($ antec $)+(0.563)$ & 0.75 \\
\hline Lowland & rech. hydg. anal. & $=(0.631)^{*}($ precip $)+(-0.506) *($ intens $)+(-0.156) *($ antec $)+(2.884)$ & 0.56 \\
\hline Upland & UZ water balance & $=(1.203)^{*}($ precip $)+(-0.579)^{*}($ intens $)+(-0.170)^{*}($ antec $)+(3.392)$ & 0.72 \\
\hline Lowland & UZ water balance & $=(0.854) *($ precip $)+(-0.737) *($ intens $)+(-0.829) *($ antec $)+(19.527)$ & 0.66 \\
\hline
\end{tabular}

$\left(R^{2}=0.92\right)$ between the hydrograph analysis estimates (Figure 7). Since estimates for both methods were based on data from the same recharge events, the relative weakness of the UZWB correlation is attributed to the fact that this method is sensitive to changes in soil moisture at individual TDR probe locations. Conversely, the hydrograph analysis method represents a rise in the water table that integrates average soil moisture content over a substantially larger volume of soil.

The anomalously high annual recharge estimates for 1992,1994 , and 1995 for the UZWB method at the lowland site can be traced to the spring recharge estimates, which exceeded total precipitation. A plausible explanation for this is that runon to the lowland site during the spring was greatly accentuated because the soil was frozen. Although we might expect the well hydrograph analysis estimates to also reflect such a process, water levels in wells respond to an area much larger than that monitored by the TDR probes. Measurement error or violation of method assumptions must also be considered as possible explanations for the anomalously high UZWB recharge estimates for the lowland site, which are therefore interpreted with some caution.

For the annual water budget at the site, Reicosky et al. (1995) estimated daily ET rates with a crop growth model, based on field measurements completed between 1992 and 1994, and produced an average annual ET rate of $47 \mathrm{~cm}$. Average annual precipitation was $72 \mathrm{~cm}$ and average annual $\Delta S$ was calculated from TDR data to be a $3 \mathrm{~cm}$ gain. These numbers imply that recharge was about $22 \mathrm{~cm} / \mathrm{yr}$ ( 31 percent of average precipitation), within the range of the site specific estimates, but somewhat higher than the site average based on hydrograph analysis (Table 3 ). Results of the stream hydrograph analysis method indicate a mean recharge rate of $12 \mathrm{~cm} / \mathrm{yr}$ (19 percent of average precipitation) in the watershed between 1992 and 1995 . This estimate is only slightly less than the average recharge rate for the site of $14 \mathrm{~cm} / \mathrm{yr}$ based on hydrograph analysis (Table 3).

\section{DISCUSSION AND CONCLUSIONS}

All of the methods provide recharge estimates in the range of 10-40 percent of natural precipitation. The only exceptions are the UZWB recharge estimates at the lowland site for 1992, 1994, and 1995, which were anomalously high, representing 61 percent to 83 percent of natural precipitation.

The fact that all methods employed in this study showed substantially larger rates of ground water recharge for the lowland site relative to the upland site provides some confidence that, indeed, focused recharge occurs beneath the lowland site. Average annual recharge at the lowland site exceeded recharge at the upland site by about 30 percent based on hydrograph analysis, 80 percent based on the CFC12 data, and 60 percent based on the UZWB method (Table 3 ). The relatively large difference indicated by the CFC-12 data could result from the longer time scale represented by the data, as the period of the hydrograph analysis and UZWB measurements had lower than average annual precipitation. Based on well hydrograph analysis of other wells in the study area, the amount of focused recharge at the R1 lowland site is greater than at most other locations in this field.

The focused recharge and the more rapid movement of wetting fronts at the lowland site is attributed to three factors: (1) surface runon of water, (2) lamellae found between one and two meters below the upland site but absent at the lowland site, and (3) coarser grained sediments at the lowland site at depths greater than about $1.5 \mathrm{~m}$.

The principal factor causing focused recharge to the lowland site likely was surface water flow (runon). Runon and subsequent infiltration was observed at the lowland site during spring snowmelt and during periods of intense or prolonged rainfall. Because of the high permeability of the soils, surface water flow was not expected to occur and therefore instrumentation was not permanently installed at either site to continuously quantify runon. For one recharge experiment on August 29, 1994, however, about $15 \mathrm{~cm}$ of 
water was applied with the linear move irrigation system and surface water collectors were installed at both sites. Runon to the lowland site for that event was estimated to be equivalent to 37 percent of the precipitation (and 55 percent of recharge). Surface water flow was never observed at the upland site. Although a natural precipitation event of $15 \mathrm{~cm}$ happens only about every 100 years in this area (Huff and Angel, 1992), evaluating the effects of such an event is nevertheless relevant to this study by providing a useful comparison of runoff at the two sites.

The occurrence of runon in an area of coarse textured soils with a relatively gentle slope of 0.02 is noteworthy. It is likely that runon and focused recharge would be even more accentuated in areas where the soils have a greater percentage of silt, clay, and organic matter and a slope that exceeds 0.02 . For example, Tosomeen (1991) found that depression focusing of recharge for clay soils was more than 400 percent of recharge in flat areas compared to less than 100 percent for silty clay and clay loam soils.

The preferential movement of dye observed at the $\mathrm{cm}$ to meter scale in the dye tracer study is analogous to the recharge of water observed at the upland and lowland sites at the decameter scale. For example, the preferential movement of dye occurred beneath microtopographic depressions whereas the focused recharge beneath the lowland site occurred beneath a much larger depression. In addition, just as the movement of dye was highly variable beneath both sites and moved preferentially (Figure 6), it is also very likely that recharge at the decameter scale is also high variable. This likelihood may help to explain some of the unusually high recharge estimates for the lowland site.

The lamellae in the unsaturated zone at the upland site may form barriers that retard the vertical flow of water because of iron oxide cement and a higher percentage of silt and clay sized particles compared to the surrounding soil. Thus, these lamellae likely retard the downward movement of water that would otherwise penetrate deeper into the unsaturated zone at the upland site. Some of the water retained in or above the lamellae could also be used by plants, further reducing water fluxes to the water table. Retention of water above or within the lamellae is a likely cause of the increased soil moisture at the $1-5 \mathrm{~m}$ depth at the upland site (Figure 3), a phenomenon that was not observed at the lowland site. Water could also be diverted horizontally along the lamellae, which terminate beneath side slope areas, contributing to subsurface soil water movement toward the lowland site (Tomer et al., 1995).

The presence of coarse grained sand below the $1.5 \mathrm{~m}$ depth at the lowland site likely allows greater redistribution of soil moisture and results in increased recharge. Athavale and Rangarajan (1988) indicated a similar direct correlation between recharge and soil texture.

The focused recharge results from this study compare favorable with results from other studies that have examined this phenomenon. Computer analyses by Tosomeen (1991), for example, indicated that depression focusing in a wide range of different climatic, soil, and topographic conditions could result typically in a 5 to 30 percent increase in recharge and that surface runon is a critical factor in causing this focused recharge. Schuh et al. (1993a, 1993b) indicated that microtopographic surface elevation differences caused water to concentrate locally resulting in greater recharge at the $\mathrm{cm}$ scale, similar to results of the tracer test conducted for this study.

The range of recharge rates estimated in this study is similar to that found in studies in humid to semiarid regions around the world, which have indicated a range of 10 to 40 percent of annual precipitation (Sophocleous and Perry, 1985; Chandrasekharan et al., 1988; Senarath, 1988; Uma and Egboka, 1988; Robertson and Cherry, 1989; Böhlke and Denver, 1995). Recharge estimates from this study also compare favorably with recharge estimates for the local region. Based on hydrograph analysis, for example, Lindholm (1980) and Miller (1982) indicated that recharge was in the range of 16 to 29 percent of annual precipitation in sand plain areas of central Minnesota.

Results of this study indicate that local variation in topography at the $\mathrm{cm}$ and decameter scale affects recharge beneath a sand plain. This finding could have important implications on ground water contamination. Agricultural chemicals such as $\mathrm{NO}_{3}$ that move readily with ground water are most directly affected by focused recharge (Delin and Landon, 1996a). Chemical data indicate that transient mounding occurred resulting in a relatively large vertical component of ground water flow and deeper penetration of recharge water at the lowland site. For example, elevated concentrations of anthropogenic $\mathrm{NO}_{3}{ }^{-}, \mathrm{Cl}^{-}$, and $\mathrm{SO}_{4}{ }^{-}$extended two to three meters deeper at the lowland site than at the upland site (Delin et al., 1997). In addition, the estimated fluxes of $\mathrm{NO}_{3}-$ and atrazine to the water table at the lowland site were 3.5 and fives times greater, respectively, than corresponding fluxes at the upland site (Delin and Landon, 1996a). Modification of application methods for agricultural chemicals, to account for varying recharge rates in different topographic settings, could result in improved ground water quality and chemical use efficiency. 


\section{ACKNOWLEDGMENTS}

This research was funded by the U.S. Geological Survey Toxic Substances Hydrology and National Research Programs and was part of the multi-state, multi-agency Management Systems Evaluation Area (MSEA) program. The MSEA program is a collaborative effort involving the U.S. Department of Agriculture, the USGS, the U.S. Environmental Protection Agency, and universities. The authors would like to thank E. Busenberg and L. N. Plummer of the USGS, Reston, Virginia, who provided the CFC analyses. The authors acknowledge USGS technical reviewers J. R. Nimmo and P. M. Jones as well as three anonymous reviewers for providing valuable comments that significantly improve the manuscript.

\section{LITERATURE CITED}

Athavale, R. N. and R. Rangarajan, 1988. Natural Recharge Measurements in the Hard Rock Regions of Semi-Arid India using Tritium Injection - A Review. In: Estimation of Natural Groundwater Recharge, I. Simmers (Editor). Kluwer Academic Publishers, Norwell, Massachusetts, pp. 175-204.

Baker, D. G., E. L. Kuehnast, and J. A. Zandlo, 1985. Climate of Minnesota: Part XV - Normal Temperatures (1951-80) and Their Application. Technical Bulletin AD-SB-2777, University of Minnesota Agricultural Experiment Station, St. Paul, Minnesota.

Biggar, J. W. and D. R. Nielsen, 1976. Spatial Variability of the Leaching Characteristics of a Field Soil. Water Resources Research 12:78-84.

Böhlke, J. K., R. B. Wanty, M. L. Tuttle, G. N. Delin, and M. K. Landon, 1999. Chronology and Isotope Geochemistry of a Transient Agricultural Nitrate Plume Undergoing Denitrification Beneath a Field-Wetland-Stream Transect in a Sand Plain Aquifer, Minnesota (in review).

Chandrasekharan, H., S. V. Navada, S. K. Jain, S. M. Rao, and y. P. Singh, 1988. Studies on Natural Recharge to the Groundwater by Isotope Techniques in Arid Western Rajasthan, India. In: Estimation of Natural Groundwater Recharge, I. Simmers (Editor). Kluwer Academic Publishers, Norwell, Massachusetts, pp. 205-220.

Delhomme, J. P., 1979. Spatial Variability and Uncertainty in Groundwater Flow Parameters, a Geostatistical Approach. Water Resources Research 15:269-280.

Delin, G. N. and M. K. Landon, 1996a. Effects of Topography on the Transport of Agricultural Chemicals Near Princeton, Minnesota, 1992. In: U.S. Geological Survey Toxic Substances Hydrology Program - Proceedings, D. W. Morganwalp and D. A. Aronson (Editors). U.S. Geological Survey Water Resources Investigations Report 94-4015, Vol. 1, pp. 555-564.

Delin, G. N. and M. K. Landon, 1996b. Multiport Well Design for Sampling of Ground Water at Closely Spaced Vertical Intervals. Ground Water 34(6):1098-1104.

Delin, G. N., M. K. Landon, R. W. Healy, and H. W. Olsen, 1996. Spatial Variability of Unsaturated-Zone Properties in Relation to Topography in a Sand-Plain Setting Near Princeton, Minnesota. In: U.S. Geological Survey Toxic Substances Hydrology Program - Proceedings, D. W. Morganwalp and D. A. Aronson (Editors). U.S. Geological Survey Water Resources Investigations Report 94-4015, Vol. 1, pp. 565-574.

Delin, G. N., M. K. Landon, J. A. Lamb, and J. L. Anderson, 1994. Characterization of the Hydrogeology and Water Quality at the Management Systems Evaluation Area Near Princeton, Minnesota, 1991-1992. U.S. Geological Survey Water Resources Investigations Report 94-4149.
Delin, G. N., M. K. Landon, K. J. Nelson, R. B. Wanty, R. W. Healy, H. W. Olsen, J. K. Böhlke, B. R. Schroyer, and P. D. Capel, 1997. Hydrogeologic and Water-Quality Data Used to Evaluate the Effects of Focused Recharge on Ground-Water Quality near Princeton, Minnesota 1991-95. U.S. Geological Survey Open-File Report 97-21.

Duke, H. R., 1972. Capillary Properties of Soils - Influence Upon Specific Yield. Transactions of the American Society of Agricultural Engineering 15(4):688-691.

Dunkle, S. A., L. N. Plummer, E. Busenberg, P. J. Phillips, J. M. Denver, P. A. Hamilton, R. L. Michel, and T. B. Coplen, 1993. Chlorofluorocarbons $\left(\mathrm{CCl}_{3} \mathrm{~F}\right.$ and $\left.\mathrm{CCl}_{2} \mathrm{~F}_{2}\right)$ as Dating Tools and Hydrologic Tracers in Shallow Groundwater of the Delmarva Peninsula, Atlantic Coastal Plain, United States. Water Resources Research 29(12):3837-3860.

Elkins, J. W., T. M. Thompson, T. H. Swanson, J. H. Butler, B. D. Hall, S. O. Cummings, D. A. Fisher, and A. G. Raffo, 1993. Decrease in Growth Rates of Atmospheric Chlorofluorocarbons 11 and 12. Nature 364:780-783.

Fortin, G., G. van de Kamp, and J. A. Cherry, 1991. Hydrogeology and Hydrochemistry of an Aquifer-Aquitard System Within Glacial Deposits, Saskatchewan, Canada. Journal of Hydrology 126(1):265-292.

Gillham, R. W., 1984. The Capillary Fringe and Its Effect on WaterTable Response. Journal of Hydrology 67(1):307-324

Healy, R. W. and P. C. Mills, 1991. Variability of an Unsaturated Sand Unit Underlying a Radioactive-Waste Trench. Soil Science Society of America Journal 55:899-907.

Huff, F. A. and J. R. Angel, 1992. Rainfall Frequency Atlas of the Midwest. Midwest Climate Center Report 92-03, Illinois State Water Survey Bulletin 71, $141 \mathrm{pp}$.

Istok, J. D., D. O. Blout, L. Barker, K. R. Johnejack, and D. P. Hammermeister, 1994. Spatial Variability in Alluvium Properties at a Low-Level Nuclear Waste Site. Soil Science Society of America Journal 58:1040-1051.

Johnson, A. I., 1967. Specific Yield - Compilation of Specific Yields for Various Materials. U.S. Geological Survey Water Supply paper 1662-D.

Keen, K. L. and 1. C. K. Shane, 1990. A Continuous Record of Holocene Eolian Activity and Vegetation Change at Lake Ann, East-Central Minnesota. Geological Society of America Bulletin 102:1646-1657.

Klute, Arnold (Editor), 1986. Methods of Soil Analysis. Part I Physical and Mineralogical Methods (Second Edition). A. Agronomy Monograph No. 9.

Kung, K. J. S., 1990. Preferential Flow in a Sandy Vadose Zone, Field Observation. Geoderma 46:51-58.

Laboski, C. A. M., 1995. Soil Physical Properties of a Fine Sand Influences on Corn Root Distribution. Master of Science Thesis, University of Minnesota, St. Paul, Minnesota, $81 \mathrm{pp}$.

Laboski, C. A. M., R. H. Dowdy, R. R. Allmaras, and J. A. Lamb, 1998. Soil Strength and Water Content Influences on Corn Root Distributions in a Sandy Soil. Plant and Soil 203(2):239-249.

Lindholm, G. F., 1980. Ground-Water Appraisal of Sand Plains in Benton, Sherburne, Stearns, and Wright Counties, Central Minnesota. U.S. Geological Survey Water Resources Investigations Open-File Report 80-1285, $102 \mathrm{pp}$.

Meyboom, P., 1996. Unsteady Groundwater Flow Near a Willow Ring in Hummocky Moraine. Journal of Hydrology 4:38-62.

Miller, J. J., D. F. Acton, and R. J. St. Arnaud, 1985. The Effect of Groundwater on Soil Formation in a Morainal Landscape in Saskatchewan. Canadian Journal of Soil Science 65:293-307.

Miller, R. T., 1982. Appraisal of the Pelican River Sand-Plain Aquifer, Western Minnesota. U.S. Geological Survey Water Resources Investigations Open-File Report 82-346. 
Nielsen, D. R., J. W. Biggar, and K. T. Erh, 1973. Spatial Variability of Field-Measured Soil-Water Properties. Hilgardia 42:215-259.

Olsen, H. W., J. D. Gill, A. T. Willden, and K. R. Nelson, 1991. Innovations in Hydraulic-Conductivity Measurements. Geotechnical Engineering 1991, Transportation Research Board, National Research Council, Transportation Research Record 1309:9-17.

Olsen, H. W., R. H. Morin, and R. W. Nichols, 1988. Flow Pump Application in Triaxial Testing. In: Advanced Triaxial Testing of Soil and Rock, R. T. Donaghe, R. C. Chaney, and M. L. Silver (Editors). ASTM STP 977, ASTM, Philadelphia, Pennsylvania, pp. $68-81$.

Omoti, U. and A. Wild, 1979. Use of Fluorescent Dyes to Mark the Pathways of Solute Movement Through Soils Under Leaching Conditions, Field Experiments. Soil Science 128(2):98-104.

Philip, J. R., J. H. Knight, and R. T. Waechter, 1989. Unsaturated Seepage and Subterranean Holes: Conspectus, and Exclusion Problems for Circular Cylindrical Cavities. Water Resources Research 25:16-28.

Plummer, L. N. and E. Busenberg, 1999. Chlorofluorocarbons. In: Environmental Tracers in Subsurface Hydrology, P. G. Cook and A. L. Herczeg (Editors). Kluwer Academic Press, Chapter 15, pp. 441-478.

Rasmussen, W. C. and G. G. Andreason, 1959. Hydrologic Budget of the Beaver Dam Creek Basin Maryland. U.S. Geological Survey Water-Supply Paper 1472.

Reicosky, D. C., J. A. Lamb, and R. H. Dowdy, 1995. Impact of Crop Water Use on Groundwater Quality. Clean Water - Clean Environment - 21st Century: Practices, Systems and Adoption. Conference Proceedings, Vol. 3, pp. 211-214.

Reilly, T. E., L. N. Plummer, P. J. Phillips, and E. Busenberg, 1994. the Use of Simulation and Multiple Environmental Tracers to Quantify Groundwater Flow in a Shallow Aquifer. Water Resources Research 30:421-433.

Richards, L. A., 1965. Physical Condition of Water in Soil. In: Methods of Soil Analysis, C. A. Black et al. (Editors). American Society of Agronomy, Madison, Wisconsin, pp. 128-152

Robertson, W. D. and J. A. Cherry, 1989. Tritium as an Indicator of Recharge and Dispersion in a Groundwater System in Central Ontario. Water Resources Research 25:1097-1109.

Russo, D. and E. Bresler, 1981. Soil Hydraulic Properties as Stochastic Processes. I. An Analysis of Field Spatial Variability. Soil Science Society of America Journal 45:682-687.

SAS Institute Inc., 1990. SAS/STAT User's Guide. SAS Inst., Cary, North Carolina, 1686 pp.

Schot, P. P. and J. van der Wal, 1992. Human Impact on Regional Groundwater Composition Through Intervention in Natural Flow Patterns and Changes in Land Use. Journal of Hydrology 134:297-313.

Schuh, W. M., D. L. Klinkebiel, and J. C. Gardner, 1993b. Use of an Integrated Transient Flow and Water Budget Procedure to Predict and Partition Components of Local Recharge. Journal of Hydrology 148:27-60.

Schuh, W. M., R. F. Meyer, M. D. Sweeney, and J. C. Gardner, 1993a. Spatial Variation of Root-Zone and Shallow Vadose-Zone Drainage on a Loamy Glacial Till in a Sub-Humid Climate. Journal of Hydrology 148:1-26.

Senarath, D. C. H., 1988. Estimation of Recharge of Sand Aquifer of the Island of Mannar Sri Lanka. In: Estimation of Natural Groundwater Recharge, I. Simmers (Editor). Kluwer Academic Publishers, Norwell, Massachusetts, pp. 423-434.

Sharma, M. L., G. A. Grander, and C. G. Hunt, 1980. Spatial Variability of Infiltration in a Watershed. Journal of Hydrology 45:101-122.

Solomon, D. K., R. J. Pereda, P. G. Cook, and A. Hunt, 1995. Site Characterization Using ${ }^{3} \mathrm{H} /{ }^{3} \mathrm{He}$ Ground-Water Ages, Cape Cod. Ground Water 33:988-996.
Sophocleous, M., 1991. Combining the Soil-Water Balance and Water-Level Fluctuation Methods to Estimate Natural Groundwater Recharge: Practical Aspects. Journal of Hydrology 124:229-241.

Sophocleous, M. and C. A. Perry, 1985. Experimental Studies in Natural Groundwater-Recharge Dynamics: The Analysis of Observed Recharge Events. Journal of Hydrology 81:297-332.

Spalding, R. F. and M. E. Exner, 1993. Occurrence of Nitrate in Groundwater - A Review. J. Env. Qual. 22:392-402.

Tomer, M. D. and J. L. Anderson, 1995. Variation of Soil Water Storage Across a Sand Plain Hillslope. Soil Science Society of America Journal 59:1091-1100.

Tomer, M. D., J. L. Anderson, and J. A. Lamb, 1995. Landscape Analysis of Soil and Crop Data Using Regression. Proceedings of Site-Specific Management for Agricultural Systems, Madison, Wisconsin, pp. 273-284.

Tosomeen, C. A. S., 1991. Modeling the Effects of Depression Focusing on Groundwater Recharge. Master of Science Thesis, University of Minnesota, Minneapolis, Minnesota.

Trudgill, S. T., 1987. Soil Water Dye Tracing, With Special Reference to the Use of Rhodamine WT, Lissamine FF and Amino G Acid. Hydrological Processes 1:149-170.

Uma, K. O. and B. C. E. Egboka, 1988. Groundwater Recharge From Three Cheap and Independent Methods in the Small Watersheds of the Rain Forest Belt of Nigeria. In: Estimation of Natural Groundwater Recharge, I. Simmers (Editor). Kluwer Academic Publishers, Norwell, Massachusetts, pp. 435-447.

U.S. Department of Agriculture, 1968. Soil Survey, Sherburne County Minnesota. Washington, D.C.

U.S. Department of Commerce, 1961-1992. Minnesota Annual Summary Reports. National Oceanic and Atmospheric Administration.

Van Genuchten, M.Th., 1978. Calculating the Unsaturated Hydraulic Conductivity With a New, Closed Form Analytical Model. Res. Rep. 78-WR-08, Water Resour. Prog. Dept. of Civil Engineering, Princeton Univ., Princeton, New Jersey.

Van Genuchten, M. Th., 1980. A Closed-Form Equation for Predicting the Hydraulic Conductivity of Unsaturated Soils. Soil Science Society of America Journal 44:892-898.

Vogel, J. C., 1967. Investigation of Groundwater Flow With Radiocarbon. Isotopes in Hydrology, International Atomic Energy Agency, Vienna, Austria, pp. 355-368.

Wahl, K. L. and T. L. Wahl, 1995. Determining the Flow of Comal Springs at New Braunfels, Texas. Proceedings of Texas Water '95, A Component Conference of the First International Conference on Water Resources Engineering. American Society of Civil Engineers, San Antonio, Texas, pp. 77-86

Warner, M. J. and R. F. Weiss, 1985. Solubilities of Chlorofluorocarbons 11 and 12 in Water and Seawater. Deep Sea Research 32:1485-1497.

Wu, L., R. R. Allmaras, J. B. Lamb, and K. E. Johnsen, 1996. Model Sensitivity to Measured and Estimated Hydraulic Properties of a Zimmerman Fine Sand. Soil Science Society of America Journal 60:1283-1290.

Zuber, A., 1986. Mathematical Models for the Interpretation of Environmental Radioisotopes in Groundwater Systems. In: Handbook of Environmental Geochemistry, Vol. 2, The Terrestrial Environment, P. Fritz and J. Ch. Fontes (Editors). Elsevier Publishing Co., New York, New York, pp. 1-59. 